ARTICLE

Received 30 Nov 2016 | Accepted 11 Jul 2017 | Published 15 Aug 2017

DOl: $10.1057 /$ palcomms.2017.80

\title{
The true-weird and the dreadful "large": post millennium American horror literature
}

\author{
Dibyakusum Ray ${ }^{1}$
}

\begin{abstract}
Debate is rife on the knowability of "true" horror, especially that which is stemmed into the "beyond", "vast" or "sublime". European Enlightenment purports that even the overwhelming Nature can be ultimately recuperated by supersensible reason. It may be the unknown, but knowing that it is so, is a "gift". You know to die, because you exist and reflect on your transience. The basic idea of the "beyond" always imagined a central role of the sentient "man" - he saw the world, and it has its meaning. We are safe or have an illusion of safety within what we know (even at the moment of peril in genre horror, we are assured that we know the nature of evil). A school of post millennial horror-thought, however, considers H.P. Lovecraft as a formidable dissent to this vein as he opines that the Nature does not care to be known/understood. The present study is on the "world-without-us" in the modern "true-weird" literature-especially in its post-millennial revival. Although Lovecraft has a considerable scholastic heritage, the revival of his peculiar nihilism in modern American horror is largely unexplored. "World-without-us" speaks of "the negative without any positive"-the "true" supernatural is manifested through the cold, relentless and utterly noncaring machinations of the "Large". The literature axial to the Large is the "true-weird"-says Lovecraft, dealing with a "defeat" of human rationality against the assaults of chaos. Likewise, the resurgence of the uncaring "Large" in literature has an important commentary on the modern society, philosophy and the critical approach to both. The recent trend consisting of Michael Wehunt, Brian Evenson, John Langan, Laird Barron or to a certain extent, Thomas Ligotti treats the eldritch (emerging from the recesses of an uncaring nature) as what Levinas might call the "absolutely other" - never (in)human, not even belligerent: but distant, hibernal and immersive. An invasive entity beyond negotiation that signals the failure of the language of rationality, thus, finds an appropriation in the post 9/11 American Horror. Therefore, is the knowledge of the Large "never one, nor homogeneous, nor totalizable, but... catastrophic"? Is the Large = Nature = Indifferent? Is Nature the "true-weird"? Is the "true weird" viablethematically or linguistically? Is a total disregard for semantics possible at all? This article aims to open an argument over the "Nature" and the "Being" in the context of American horror literature, and how it transmutes the genre expectations of the canon.
\end{abstract}

\footnotetext{
${ }^{1}$ NIT Silchar, Humanities and Social Sciences, Silchar, Assam, India
} 


\section{Introduction}

W

hile not post-millennial in the generational sense, "The Frolic", the opening story of Songs of a Dead Dreamer (1986) by Thomas Ligotti (2011), might set the thematic overlay of the argument to come. David Munck, prison-doctor of idyllic American small-town Nolgate, witnesses the abduction of his daughter Norleen by escaped inmate John Doe. A man sans any conceivable identification, John Doe previously puzzled Munck during the former's psychologicalevaluation by his cryptic statements. His crimes are never specified, his origins unclear by his tendency to speak in variant accents and tone, and his only passion is "Frolicking" in a realm of pure irrationality-a "phantasmagoric mingling of heaven and hell" (Ligotti, 13). As Munck ponders over Doe's visions and possible history of unspeakable crime against children, John Doe, presumably, kidnaps the sleeping Norleen through the bedroom window, leaving a farewell letter for the good doctor. We know nothing about his destination, and only a lurid hint of the possible fate of the child is offered. What remains is a vague sense of foreboding, a hazy terror that shatters the tranquility of the idyllic American family: "... We leave this behind in your capable hands, for in the black-foaming gutters and black alley of paradise, in the dark windowless gloom of some intergalactic cellar, in the hollow pearly whorls found in sewer like seas, in starless cities of insanity, and in their slums... my awestruck little deer and I have gone frolicking. See you anon. Jonathan Doe" (Ligotti, 18).

This article is on the invasive "world-without-us" in the modern true-weird American literature in its post-millennial revival. There is-a less populist strand of the American horror seems convinced of it-a cluster of unreason at the heart of the world-intelligible: the world perceived to be nourishing, plausible and mostly responsive to human attempt of understanding it. A failure of language, "The Lure of Devouring Light", 1 a "thought of the impossibility of thought" seem to have infiltrated the American literature ever since "a dark realization of that fantasy life, in the sense that it turned the nightmare, of a ruthless other threatening the fabric of buildings and of the nation, (turned) into a palpable reality"2 (Griffin, 12). Although the post 9/11 literary tropes are beyond the purview of this argument, the advent of the Large in the modern Weird fiction is forcefully reminiscent of the loss of Reason as the towers came down; and a nation had to admit the presence of an "other" it could not understand. This essay puts such "bewilderment" in the backdrop of a Lovecraftian tendency in a cluster of modern American Literature-a coming-to-terms with a lack of rationality and reason by avowing the presence of something not-understandable-the "Large". This "Large" is the antithesis of the familiar. It is also the presence outside the window of comprehension that does not elicit any emotion (fear, hostility, repugnance, even curiosity) but dread. Dread that is a "vertigo of freedom"; that impulse to willingly dive into the abyss-as Kierkegaard puts it in The Concept of Dread (Thacker, 2015: 118). The hostility of the classical eldritch is engulfed by the "unfocused fear before the abyss of uncertainty" (Thacker, 2015: 118) in the post millennial American horror, at least in a certain section of it.

One of the key concepts to be unraveled to approach this topic is the "world-without-us" introduced by Eugene Thacker (2011) in Horror of Philosophy, Vol. 1 (5) (and later illustrated in Vol. 3), which is a foil to the "world-intelligible" explained earlier as sentient, forbearing, challenging but finally acquiescing to the attempts of human beings trying to make sense of it. The paper keeps referring to Lovecraft in this article because of his strict adherence to-as it will be shown later-a thematic negation of world-intelligible in his fiction and essay (a tendency, it's argued, enjoying a renascence in the fiction-cluster dealt with in here), but the focus remains on the "anti-intelligible" in the last decade's American horror. Lovecraft's rejection of mortal reasoning is resuscitated by this non-mainstream strand that focuses on alienation, desertion, violent encounters and the irredeemable. These narratives offer partial or no resolution to the crises they function around, are mostly insular to logic or rationality, and uninterested in the archaeology of the occult but in the disarray it creates among characters. Ligotti is germane in the prelude of this argument simply because of his persistent (as we shall later look at a more recent short story by him) denial of the ratiocination of evil. The "world-intelligible" is undone before John Doe. His world is "without-us", because the world "with-us" is subjected to our rationality, and Doe's villainy is beyond recognition or reason. Munck goes mad in the climax as his grief is coupled with the terror of unknowing. This article argues that the resultant "world-without-us" speaks of "the negative without any positive" - a concept beyond concept, that is also the genesis of sentient consciousness.

In the three volume seminal text on the philosophy of horror, Thacker talks about a reading of the extant critical tradition recast into a drift between Reason and Un-reason. This lacks the starkness of good/evil, holy/unholy or even Life and Death, especially because the Large-as the post-millennial horror argues-is the sentient quiddity which was and will be. Reason is just an upshot that re-affirms its negative. We, the conscious beings, perennially stand at the precipice of comprehension, looking out at the darkness beyond comprehension-the vertigo and/or the dread. According to Thacker, who considers H. P. Lovecraft's writing as the literary embodiment of this philosophy, the true-weird manifests itself as an essentially unknowable margin that, more often than not, resides in unfathomable openness: a forest, the night, a sea, an open field or simply, the Nature. The nonspecificity of nature-from a "black bark" to the icy vastness within constellations-has been a staple motif for the venerable tradition of Weird fiction. Lovecraft dreamt of agoraphobia in the British rurality in the form of subterranean ghost city and rats in the wall, Arthur Machen knew the misty mountain scenery might roll back to reveal a terrifying pagan cavort. In the context of modern American literaria, the true-weird brings this unearthly largesse to a nation invaded by a nameless, faceless enemy: darkness beyond the headlight presses against the lonely diners' windows, and the trucker inside hesitates to take one step outside ("Greener Pastures"); the ice breaks on the river on a grey morning as a newly orphaned child hits puberty at last ("Premature Communication"); a Leviathan arises from an ocean of ink at an uncharted location that is just beside the Hudson River (The Fisherman) - "time and space had become a mockery" (Lovecraft qtd. in Thacker, 2015: 121). An invasive entity beyond negotiation that signals the failure of the language of rationality, thus, finds an appropriation in the post 9/11 American Horror, rendering something, as Don DeLillo (2001) puts it: "empty in the sky".

Yet, the sheer implausibility of the supersensible proves to be a thematic/linguistic trammel. How can the unknowable be rendered in something as constructive as a prose literature? How is the act of composing a plot be equipped for a dispersal of meaning? Is the Large knowable? If not, how can a knowledge system forever remain axial to a non-conclusion?

\section{"...it would hurt him": Invasion, Hostility and Recognizing the Eldritch}

Post millennial horror authors-Michael Wehunt, Laird Barron (2014) or Brian Evenson (2016a, b) treat this concern through what I call a dissociative writing. This, I feel is again a silent 
homage to Lovecraft, as Graham Harman (2012), analysing the object-oriented philosophy in Lovecraft's literature, notices the "de-literalizing gesture" as his major stylistic trait. Lovecraft, according to Harman, half-disclaimed the shape of the aberrant as possibly a feverish imagination, then obfuscated the essence of the monster further by inviting the reader not to ponder on the minute details of its body, but on a more "general outline". An octopus-dragon-human hybrid is thus rendered "something over and above the literal combination of its elements". (18) The reader looks at the unthinkable, yet he is made partially blind. He sees yet he does not, maybe because the "I" and the "eye" lose synchronicity facing the cosmic eldritch. The modern American true-weird has repeatedly negotiated with the indescribable through similar dissociative fashion, as will be shown shortly.

Consider, for example, a story on the invasive Weird-instead of a quiescent eldritch (which is in most of Lovecraft and directly Lovecraft-inspired literature), the Large makes its presence felt in a classic supernatural fashion: a rap on the window, a shadow in the corner, a spectral disquietude in the heart of an urban setting. Brian Evenson's "The Window" tells the story of an unnamed protagonist whose account might or might not be a trance: "He was all but asleep. Or he was asleep and then the sound woke him. Or he was dreaming and never awoke at all" (Evenson, 181). The story itself, as will be clearer later, is a meditation on incertitude. The protagonist-"He"-wakes up hearing a sharp rap on the window. He is confused, and confusingly opaque in his slow cognition. It basically takes the story several hundreds of words to figure out the source of the disturbance-a disembodied, vaguely shining anthropomorphic figure at the corner of the darkened room, floating through. The man is not sure what he is seeing, not even whether he is in his senses, and Evenson dissociates the spectral even further from reality as the shadow lumbers through the room perfectly unaware of anything else in the surrounding. It bumps into furniture but never changes its course, and doesn't seem to hear the protagonist gasping. The non-description of this "partly shadow rather than body" (Evenson, 183) shows a failure of the rational for the protagonist and the author alike as Evenson visibly struggles with his own writing: "It was the shape and size of a human but indistinct, it's edges blurred somehow, as if it were not existing here precisely at all, but instead existing somewhere else, in a place that happened, somehow, to overlap with this space" (Evenson, 184). The classical genre tropes of "haunting" are subverted, because Evenson is invested in a perennial alienation between two worlds -none knows the other, one sees but does not understand, the other feels but does not bother-both captured at an inconceivable overlapping between the two. There is no latent theme of vendetta, dogged persuasion or unfinished business, at least not till the protagonist decides to react against this invasion:

Almost without knowing what he was doing, he hurled the book at it. The book struck but went through, not even slowing down, and struck the window behind it, making it shiver before then falling to the floor. The figure stopped abruptly ... heading toward the other window, the one that was open ... in his rush to shut the window, he managed to close it right on the figure itself. (Evenson, 185).

The window severs the figure, two halves landing on either side of the glass. "He" calls the police while watching the swath of blood on the wall and floor slowly fading away, and the whole episode is dismissed as false alarm. The narrative seems unsure whether the whole thing was a dream, but " $\mathrm{He}$ " is sanguine that there will be a payback. It was a case of nothing-ness assuming corporeality, an invasive outside suddenly aware of the innate hostility of the other. "He had hurt it, and now it would hurt him" (Evenson, 186). A mutual dawning opens a gulf of belligerence between entities ontologically alien to each other, and violence is the only way they can communicate with. "He" is certain that it would come back for him, to exert the same violent denial the shutting of the window signified. There will be blood, and "He" will be gone.

At least in this particular story, Evenson speaks of not so much of the terrifying nonchalance I am interested to touch upon, as he does of the friction with the Large that leads to a discernment of the other, which illuminates "all the dark corners in which the I's mastery would be challenged" (Levinas, 2006, 121). Yet, this challenge is not without a certain comfort. I must retrace the core idea of super-sensibility a little to elaborate this point. The notion of a blasé expanse is not without its thematic struggle, being grappled with since the Enlightenment. The motif of the Large here, let it be reminded, is Nature. Nature is unknowable, but you know - as a warm, reassuring gesture to your humanity-that you cannot know it. The subject crawls out of the prison of selfish appreciation to discover that Nature can be pleasing universally. Nature, however, does not aim to please, nor does it create awareness of its perfection and harmony-the human subject can only strive for coherence for the supreme knowledge, the ultimate beauty beyond reach. Even at its full unreadable aura, Nature does submit itself to our sensual appreciation; the "sublime" frustrates, yet enthralls us with its artistic possibilities. The absence of conclusion opens up an array of unique approaches. The beauty is the constancy of trial. How can that which is apprehended as inherently "contra-final" be noted with an expression of approval? It can, because the sublime "can be called into the mind by that very inadequacy itself which does admit of sensuous presentation." (Kant, 25) We are assured that we are allowed to try to understand the mystique.

Immanuel Kant was writing about the uncaring cosmos inadvertently granting glory to mortal failure in The Critique of Judgment (1790). Its connection to an apperception of the threat of the Large has been addressed by Eugene Thacker in Vol. 3, where he deduces that this approach to the non-realization of the cosmos is a "consolation prize". "We can, at the very least, comprehend this incomprehension-we can think the failure of thought". The horror of the Large "is ultimately recuperated by reflexive, supersensible reason, and thereby domesticated within the confines of an internalized self correlating to an external world" (Thacker, 118). It will be a mistake to assume that the nature of this assurance is always congenial. Evenson's "He" has a terrifying experience, and he knows that there will be repercussions, but he, at least, knows the surety of a reprisal. The horror of belligerence is dependent on the cognition of the opposite. We fight our enemies because they are cognizably contra. "He" spends sleepless nights because irrespective of his slipping grasp on reality, "He" knows it will take vengeance. This is, by Enlightenment standards, the beauty of mortality-you try to know the Large, although you may fail or die in the process. It does not necessarily allay the potency of the Large as a trope of horror, but it indeed creates a space of reading the apparent inscrutability of the invader. What is the intent? How sound is the strategy? Can it be countered?

In the passing, we may look at "Premature Communication", from the book Teatro Grottesco (2008) by Thomas Ligotti, for a similar treatment. Densely cryptic, and completely dissociative of the spatial or temporal logistics of the plot, PC looks at a snowgrey world through the eye of a "child". Ungendered and devoid of direct speech, this character is put under house-arrest by parents on a wintry morning and transferred soon to a hospital. "The ice is breaking up on the river" (42) - knows the child from a spectral voice that follows day and night, like a foreboding prophecy. On their way to the hospital, the parents are killed as 
the ice breaks up on the river and their car is drowned (Ligotti never specifies the nature of the "'tragic event" (43), but the child knows, as the reader knows). Yet it does not matter. The snowflakes still fell one by one outside the window, the child needs no explanation because "The ice has broken up on the river"' (43).

The invasive Large has an engulfing presence here, much intense than "The Window". The Weird is never explained, not even starkly visible, never a shadow, a spectre or an abomination that terrorizes the protagonist. Yet, we are somewhat assured by our realization that the story is (possibly) a meditation on puberty. The story can be read as an elegy to the first days of sexual awareness, familial suppression, isolation and violence. Maybe, every narrative of coming-of-age secretly demands the death of gerontocracy. Maybe, the child's hands are restrained by the phobia of masturbation. The spectral sound like a heap of rusted machinery can be the broken voice of a pre-teen child, and the darkness of growing up under the shadow of Puritanism can breed violence and/or frigid distance. The sheer symbolic force of the story grants the reader agency over the Large: "Even those anomalous moments, in which the senses threaten to overwhelm reason, are, in the end, recuperated within reason's comprehension of its being overwhelmed" (116) — we come back to Thacker again, critiquing Enlightenment's response to the philosophy of horror. You are afraid, but you know that you are afraid, and why. The Large is readable.

In retrospect, the post-millennial true-weird till this point, is removed from "A vast, sepulchral universe of unbroken midnight gloom and perpetual arctic frigidity" (Lovecraft, qtd. in Joshi, 145). Lovecraft himself was astringent about this strain "of a cosmos which gives a damn one way or the other about the especial wants and ultimate welfare of mosquitoes, rats, lice, dogs, men, horses, pterodactyls, trees, fungi, dodos or other forms of biological energy" (148). Even, the unfeeling supernatural has a deceptive, swindling insidious retinue of evil that actively engages with humanity in some true-weird fictions. John Langan's (2016) novel The Fisherman is about the surreptitious presence of cosmic horror in upstate New York. This is a place that draws people in distress, by luring them with a promise of resurrection of the departed. The story opens with the bonding of two aggrieved widowers who find solace in fishing as an intense hobby. Their quest for undisturbed fishing reserves take them to the Dutchman's Creek, leading up to the Ashokan reservoir. Langan slyly plays with the metaphor of fishing as the duo continues their quest to find redemption from their grief. Before long, however, it becomes clear that an ancient evil lurks deep beneath the waters, and somehow the whole place has a mystical connection to an ocean of despair-an otherworldly sea that harbours immense creatures ready to invade the worldintelligible. What they require is a fisherman-a navigator who will bring them to the shore; hence the entrapment of the aggrieved, unsuspecting protagonists.

Although, there is the depiction of a Lovecraftian Leviathan and the black sea of despair and sadness, the novel constantly sets the evil as dependent on the ascendancy over human emotions. The largest part of the novel, narrated in flashback, talks about the sordid past of Dutchman's Creek in the early twentieth century. Once a colony of mostly European expatriates working as menials for the construction of the Ashokan reservoir, the location was haunted by an ancient sorcerer who-as revealed throughout the remainder of the novel-was planning to unleash the wrath of the empyrean creatures of yore on Earth. This scheme required human subjugation and fealty, and the return of the deceased loved ones in undead form was the bait. Moreover, the evil magic was thwarted by good magic cast by a human, though the traces of the former remain to haunt and feed upon the despair of our aggrieved widowers. Langan provides enough hint that the true evil lurking into the stygian sea can never be understood or vanquished due to its sheer divinity, but its ascension can be halted by mastering over the mortal failures. The same happens in the climax, where the invasion is thwarted by coming to terms with "unreality" of the idea of resurrection. A purely human cognitive endeavor thus significantly alters the cosmic operations.

Evenson knew that the other shall take its revenge, Ligotti equated the Large to the awakening of dark impulses, Langan relates the negotiation with the inevitable to a Kantian proportion of comprehending the incomprehensible. "It" cannot be understood, but it can be understood that "It" is beyond reach. Although treading firmly on the path of the Lovecraftian tropes, this section of American horror attempts to stall the full triumph of the irrational over reason. Reason is defeated, but it knows its defeat.

\section{"You're not my Lizzie": the World-without-us and the Vertigo of Not-knowing}

The reason of reiterating Lovecraft is his dispute with Enlightenment. If we proceed with Thacker's polemics further, we shall see how Lovecraft is considered a direct opposition to the "readable" Large. Thacker invokes the 1927 essay "Supernatural Horror in Literature" where Lovecraft does not maintain the same faith in supersensible reason we see in Kant. The "domestication" of the cosmic by Kant treats the Large as an essentially human experience, whereas Lovecraft's horror is not there as a limit to thought, but the horror "is that thought-all thought, since for Lovecraft everything is absolute-all thought is paradoxically constituted as limit, a strange but perhaps enchanting abyss at the core of thought itself" (Thacker, 2015: 120). Thacker quotes from "The Shadow Out of Time" (1936) where the protagonist has to confront the possibility that his dreams of otherworldly entities might be a reality. He suffers a convulsion at the very hint of this, collapses on the floor and experiences an inability to think-a sequence Thacker calls "the vacuity of any correlation between subject and object, between self and world" (121). The Lovecraftian brand of horror is extended beyond the anthropy/ misanthropy binary-the supernatural does not concern itself with being hostile to the cognitive subject, it simply remains beyond the threshold of meaning-making. The result is a collapse of rationality, or, as Graham Harman puts it: "literary cubism" (123). The potency of dissociative writing thus bolsters a perfect alignment of the thematic and stylistic, because the description of the Lovecraftian eldritch always escapes concretization. The general outlines are all there, but they curiously fall short of "adding-up" to a whole. All we see are disparate hints that enforce the aforementioned "vacuity" between subject and object, rendering it beyond-thought. In Lovecraft, Harman has seen how "numerous bizarre or troubling features of a palpable thing are piled up in such excessive number that it becomes difficult to combine all these facets neatly into a single object, thereby giving us the sense of a purely immanent object that is nonetheless distinct from any bundle of features" (123). How do we conceive something contrastive of its own parts? It's probable that this significant un-answerability has contributed greatly to a section of post-millennial American horror. We have already witnessed the "readable" Large. Can horror literature be any more inscrutable, or Lovecraftian in a truer essence?

The present study shall cite three examples with varying details. The eponymous short story of Michael Wehunt's collection Greener Pastures (2016) describes the solitary trucker Forsyth on his way through the Deep South. He meets another fellow trucker in a lonely diner about to be closed down for the night, as the latter spins his unsettling, nihilistic philosophy about 
"the space in between" (35). The latter is curious what it is that constitutes the entire gulf between urban oases swathed in neon light. There are not many lights on the highways, not enough patrol cars; the misery and seclusion sometimes speak through a veil of unknowability. The drivers dream, or they really hear voices calling out to them, the sky dripping on them and the night folded like a blanket. Sometimes they go missing in thin air, only their trucks left behind as a residue of some cosmic joke. The other trucker keeps talking as Forsyth feels the night getting darker around the diner, even colder. The only voice one can depend upon to preserve their sanity, the other trucker says, is the voice of the radio, but that does not efface the vision of pale figures waiting in the darkened woods on either sides.

"Lovecraftian" is used rather casually in modern American mass-media. There was incongruity in Lovecraft's own philosophy as well; lapses mostly owing to zeitgeist-a strong undercurrent of Orientalism including phonetic othering of Eastern sounding names, tendencies explicable now through postcolonial critical framework. The Lovecraftian, in short, inevitably loosened its grip over the unmaking of Rationalism, creating a space for anything involving a "mysterious" eldritch-from creature to body horror-to identify itself to the moniker. Wehunt is Lovecraftian not because there is a general supernatural mystique in the majority of his stories, he is not Lovecraftian because of the ubiquitous decadent paranoia of the twilight of imperialism (Wehunt is, if anything, deeply concerned with the alienation of the increasingly bourgeois urbanity)-he is Lovecraftian by the dint of the inscrutable theoretical challenge his brand of supernatural imposes. Although there is a mention of humanoid shapes in "Greener Pastures", they are never the frontispiece. The focus is on the unfathomable darkness that descends on the diner as the two truckers talk. The dark is active outside. The lights flicker and go off one by one. Forsyth receives a call from his daughter who beckons him into the woods outside, while he knows it is not practically possible. The diner is almost magically deserted, and Forsyth tries to stave off the terror: "You're not my Lizzie" (41). He tries to escape the "creepy" place, but he is left alone in the dark as there is a small laughter from somewhere close, as the last light on the roof winks and is gone.

The Large is non-negotiable, unidentifiable and disconnected. If one section of the post-millennial true-weird puts the Large and the "self" on the familiar grounds of recognizing the other as hostile, the other section, at the outset, focuses on the "indifferentism": "Purely universal, cosmic and eternal a phenomenon to have any relationship to the immediate wishing-phenomenon of one minute organic species on a transient and insignificant planet" (Lovecraft qtd. in Thacker, 2015: 125). "You're not my Lizzie"- then, who are you? Who is the other that swirls beyond the orb of human cognition? Any glyphic incumbency of the story is kept in tight check, and the unreadable remains unreadable. It can only produce vertigo of perfect dissociation, as happens when Jonathan Doe takes away the daughter of Dr Munck to "some intergalactic cellar", and the hapless father loses his mind into some obscure hell. This essay started with this quotation in search of the edge of pure unreason, and the second phase of the post-millennial true-weird seems to have found it. Wehunt piles the genre horror tropes-the solitary diner, the abandoned toilet, lurid neon lights flickering menacingly, sudden disappearance of people, a creak of the door, whispering voices in the back-but cautiously keeps away from any tangible threat, while spinning an aura of inconceivability which remains unreadable to the last. Something is luring lonesome drivers into the darkness beyond the reach of neon-lit urban spaces, using their longing for the domestic comfort as bait. The Large does not invade, it recedes from the periphery of consciousness, and those who recede with it never come back to tell the tale.
Although this article displays a slow progression towards the submission of reason before the unknowable, this progression is not author-specific or even chronological. Whereas "The Window" is about the hostile "other", Brian Evenson himself offers stories, which take the theme of hostility away from invasion narrative. "Black Bark"-the opening story of A Collapse of Horses-is about a man finding a piece of black bark in his coat pocket, and is unsure how it got there. He tosses it away, but it comes back inexplicably. He threw it in the fire with the same result. When he tried to smash it with a hammer, it looked at him with an eye that magically appeared on it. The man could not look away till the black bark closed its eye. "So the man lifted it up careful as he could, put it in his pocket, and left it there until he was dead. Once he was dead, it did not have no use for him" (Evenson, 9).

This story within a story has a genre superstructure with a history of using large spaces aesthetically. "Black Bark" is a Western, where two travelers are set for an unknown destination, and/or running from mysterious assailant(s). Sugg is heavily bleeding and is about to die; yet he persists somehow and tells Rawley the aforementioned parable. Days pass, the journey does not end, and ennui besets Rawley while Sugg becomes increasingly anemic and delirious, yet does not die. No explanation is given of Sugg vanishing and then reappearing before the fire with clothing stiff with blood. He seems to be in no pain and being singed with fire apparently does not bother him anymore. He just wants to tell Rawley of "not black bark. The story of everything black bark left out" (Evenson, 12). Gripped by a sudden terror, Rawley cannot speak, and (not-) Sugg begins the tale as the story ends. The rugged mountain terrain, the impending dusk, the fatigue, the silence-all contribute to an abstruse unease, without explaining anything. There is just an "other"- not hostile or execrable-that has a story to tell... its story to tell. We come back to Thacker, who terms this moment as the "black illumination": "... a degree zero of thought, inaccessible to the senses, unintelligible to thought... frozen thought of an enigmatic epiphany" (128). Suggs' story of the black bark, we understand, are not meant for the mortal ears, which is why Evenson's story concludes as the other story begins. There is no invasion here: the Large did not move inside through the window, it's actually the men who happen to inhabit a faction of the expanse. ${ }^{3}$ Rawley is not being forced to listen to the story, yet he is transfixed as if looking into an unfathomable abyss-fighting the mad urge to plunge. The Large confounds, but never reveals itself, because revelation is a device of the self to make meaning of the world. The world does not care.

Ergo, "Black Bark" uses its genre trappings to signal a truth beyond the rationalistic outlook. The black bark brings in the Large, and there it stops, because everything "not black bark" is beyond comprehension, its mere glimpses are enough to drive the onlooker insane. "The Forest" by Laird Barron reintroduces this cosmic (non)-narrative by placing the Large in the vast, unforgiving Nature. Richard Jefferson Partridge, up and coming Hollywood film director, makes a trip to a remote hamlet of New England, drenched in icy mist hanging over the woods, where Dr Toshi Riyoko conducts a clandestine research. Moorehead Estate is adjacent to the long abandoned village. Once thriving, the village fell into hard times as a long, deadening winter came, and was ultimately abandoned. Barron uses the motif of this village to signal the ephemerality of the human civilization, which is also a collateral philosophical output of Riyoko's entomological experiments: "Hell of a lot of insects, hmm?... We'll be dead as Dodos a goodly period before they emerge to claim the surface... But trust that their rule will make the reign of the terrible lizards seem a flicker of an eyelash" (26).

It soon turns out that the credence of Riyoko's experiment is inverted: he is not discovering the bugs; he is discovering that we are the bugs. The logistics remain unexplained, but we learn that 
the research has successfully established an inter-dimensional connection with a timeless civilization of pure chaos. The mortality of the human existence, a thematic mainstay of the story, serves as a foil to the eternity of this terrifying universe. It is a world beyond cognition, but "they", ironically are interested in preserving aspects of the transient human culture, and-on special occasions-consciousness. Deific and numbing at the same time, Barron uses this concept as a snide satire of the rationale of human existence: it is possible to cross over into this universe, but the flesh must be sacrificed as a rite of passage, "and exist among them in a state of pure consciousness" (32). Immortality, thus, is taken beyond mortal discernment, and the protagonist cannot handle the revelation at the end of the story, "He reached up and pulled the shade down tight against the sill and it was dark" (32). The very brief description of the civilization itself occurs when Partridge is submerged in an isolation tank, which acts as a portal into the Large. The experience is momentary, but unbearable: "Fire and blood and moving tides of unleashed water. Bones of men and women and cities. Dead, mummified cities gone so long without inhabitants they had become cold and brittle and smooth as mighty forests of stone... In the distance the sun heaved up, slow and red. Its deathly light cascaded upon the lines and curves of cyclopean structures. These were colossal, inhuman edifices..." (Barron, 2014, 27-28).

\section{Conclusion}

The article offers a discussion on the true-weird in modern American fiction, and the striation therein. The fictions chosen are all coeval; mostly from the same decade, yet their approach to the Lovecraftian tropes of the "Large" seem to have a "progressional" strain. Section "...it would hurt him" perceives the Large mostly as the hostile other, and obsesses over its intent and revenant nature. The stories in this section cannot stop wondering even if they cannot find the eldritch's true nature. Further, this hint of a truer nature of the horror endows the perceiver an agency over the other. The Large might be unstoppable and vengeful, but at least the victim knows that it is unstoppable and vengeful.

Section "You're not my Lizzie" is where the stories ponder over the Weirdness. The other becomes the true other in the sense that it forfeits hostility in favour of a verity of chaos, a dominion of entropy. This section steps back from the precipice of the knowable-a jump afar is presumably beyond the scope of modern epistemology. The Large simply does not care, it continues its otherworldly machinations paying absolutely no attention to the mortal crises of the beings attempting to read it. A glimpse of it might mean madness or obliteration-not because it is hostile, but because it is beyond cognition. The failure of humanity as such thus makes a renascence in this type of American horror that may or may not have its revivalist strains stemmed in the post 9/11 literary scenario. Richard Gray has talked about how the entire American literaria found itself-sans language or reason-as benumbed witness of the ascension of a post-lapsarian world after destruction of WTC (10-16). Is the modern trueweird dedicatedly axial to a nation's loss of innocence? Is it part of a bigger literary activity that sustains on post-Reason? This essay can be an initiation of such a colloquy.

\section{Notes}

1 Griffin, Michael. (2016). The Lure of Devouring Light. California: Word Horde. p. 332.

2 Richard Gray's After the Fall: American Literature since 9/11 talks about the recurrent motif of un-reason and failure of meaning-making in the literature produced after the destruction of the WTC.

3 One is reminded of S. T. Joshi in The Evolution of the Weird Tale (2004). While describing the materialism in Lovecraft's literature, Joshi writes: “Those of Lovecraft's alien races who still inhabit the dark corners of our planet are not cowering in fear of humanity; indeed, they are allowing us to dwell on this planet." (Joshi, 76).

\section{References}

Barron L (2014) The forest. In: Occultation. Night Shade Books: New York, NY, pp 5-32.

DeLillo D (2001) In the ruins of the future. [online] The Guardian. Available at: https://www.theguardian.com/books/2001/dec/22/fiction.dondelillo. Accessed at 30 September 2016.

Evenson B (2016a) Black bark. In: A Collapse of Horses. Coffee House Press: Minneapolis, MN, pp 1-12.

Evenson B (2016b) The window. In: A Collapse of Horses. Coffee House Press: Minneapolis, MN, pp 181-186.

Griffin M (2016) The Lure of Devouring Light. Word Horde: Petaluma, CA.

Harman G (2012) Weird Realism: Lovecraft and Philosophy. Zero Books: Hants, UK.

Joshi ST (2004) The Evolution of the Weird Tale. Hippocampus Press: New York, NY

Langan J (2016) The Fisherman. Word Horde: Petaluma, CA.

Levinas E (2006) Entre Nous. A\&C Black: Edinburgh and London.

Ligotti T (2008) Premature communication. In: Teatro Grottesco. Vintage: London, pp 41-44.

Ligotti T (2011) The frolic. In: Songs of a Dead Dreamer and Grimscribe. Penguin Books: New York, NY, pp 3-18.

Thacker E (2011) In the Dust of this Planet: Horror of Philosophy, Volume 1. Zero Books: Hants, UK.

Thacker E (2015) Tentacles Longer Than Night: Horror of Philosophy, Volume 3. Zero Books: Hants, UK.

Wehunt M (2016) Greener pastures. In: Greener Pastures. Shock Totem Publications, LLC, pp 31-42.

\section{Data availability}

Data sharing is not applicable to this article as no datasets were generated or analysed during the current study.

\section{Additional information}

Competing interests: The author declares that there are no competing financial interests.

Reprints and permission information is available at http://www.palgrave-journals.com/ pal/authors/rights_and_permissions.html

How to cite this article: Ray D (2017) The true-weird and the dreadful 'large': post millennium American horror literature. Palgrave Communications. 3:17080 doi: 10.1057/ palcomms.2017.80

Publisher's note: Springer Nature remains neutral with regard to jurisdictional claims in published maps and institutional affiliations.

This work is licensed under a Creative Commons Attribution 4.0 International License. The images or other third party material in this article are included in the article's Creative Commons license, unless indicated otherwise in the credit line; if the material is not included under the Creative Commons license, users will need to obtain permission from the license holder to reproduce the material. To view a copy of this license, visit http://creativecommons.org/licenses/by/4.0/

(C) The Author(s) 2017 